\title{
БИОЛОГИЯ
}

УДК $581.9: 598.2(571.54)$

DOI: $10.18101 / 2542-0623-2020-2-7-23$

\section{СОСТОЯНИЕ РАСТИТЕЛЬНОГО ПОКРОВА ОСТРОВОВ ЧИВЫРКУЙСКОГО ЗАЛИВА НА БАЙКАЛЕ В УСЛОВИЯХ вЛИЯНИЯ кОЛОНИй ОкОЛОвОдНЫХ ПтИЦ}

\author{
О. А. Аненхонов, Е. В. Бухарова, А. А. Ананин \\ (C) Аненхонов Олег Арнольдович \\ доктор биологических наук, \\ Институт общей и экспериментальной биологии СО РАН \\ Россия, 670047, г. Улан-Удэ, ул. Сахьяновой, 6 \\ anen@yandex.ru
}

(C) Бухарова Евгения Васильевна

кандидат биологических наук,

Заповедное Подлеморье

Россия, 671623, Республика Бурятия, пос. Усть-Баргузин, ул. Ленина, 71

darakna@mail.ru

\author{
(C) Ананин Александр Афанасьевич \\ доктор биологических наук, \\ Заповедное Подлеморье \\ Россия, 671623, Республика Бурятия, пос. Усть-Баргузин, ул. Ленина, 71 \\ Институт общей и экспериментальной биологии СО РАН \\ Россия, 670047, г. Улан-Удэ, ул. Сахьяновой, 6 \\ a_ananin@mail.ru
}

Аннотация. Колонии околоводных птиц оказывают значительное влияние на растительный покров островов. На Байкале острова с гнездовыми колониями сравнительно немногочисленны. В статье приводятся результаты обследования растительного покрова трех колонизированных птицами островов Чивыркуйского залива на Северном Байкале: Голый Кылтыгей, Покойницкий Камень, Белый Камень. Приведены результаты исследований, показывающие характер трансформации растительного покрова этих островов. В частности, отмечены обеднение состава их флоры, повышенная мозаичность растительности, отмирание деревьев и целых лесных сообществ, высокое обилие нитрофильных видов растений в сообществах. Подчеркивается, что происходит адвентизация растительных сообществ за счет повышения фитоценотической роли некоторых заносных видов, но повышения адвентизации флоры не обнаружено. Отмечено, что воздействие колоний птиц на Чивыркуйских островах аналогично таковому на морских островах. С учетом естественности высокой численности баклана сделан вывод о том, что орнитогенные процессы трансформации растительного покрова не следует расценивать как негативные.

Ключевые слова: флора; растительность; большой баклан; монгольская чайка; орнитогенные факторы; трансформация растительного покрова; Байкал; Чивыркуйское семиостровье. 


\section{Для цитирования}

Аненхонов О. А., Бухарова E. В., Ананин А. А. Состояние растительного покрова островов Чивыркуйского залива на Байкале в условиях влияния колоний околоводных птиц // Природа Внутренней Азии. Nature of Inner Asia. 2020. № 2(15). С. 7-23.

DOI: $10.18101 / 2542-0623-2020-2-7-23$

\section{Введение}

Растительный покров островов, как и вся их биота, будучи пространственно четко отграниченным объектом, представляет собой весьма интересную модель для изучения широкого круга вопросов биогеографии, экологии и биологии [MacArthur, Wilson, 1967]. Острова благодаря определенной изоляции за счет открытых водных пространств благоприятны для формирования гнездовых колоний околоводных птиц, поскольку представляют собой относительно защищенные от хищников территории [Anderson, Hodum, 1993; Oro, Ruxton, 2001; Natusch, Lyons, Shine, 2017]. Нередко эти колонии достигают значительной численности и вследствие этого оказывают многостороннее и существенное воздействие на наземные экосистемы. Такие воздействия являются предметом исследования в основном на морских и океанических островах [Бреслина, 1987; Мочалова, Хорева, Зеленская, 2005; Хорева, Мочалова, 2009; Иванов, Булочникова, Романенко, 2010; Ellis, 2005; Natusch et al., 2017; и др.]. На островах и побережьях пресных водоемов целенаправленные исследования такого плана единичны [Ishida, 1996]. На Байкале также специальных исследований не проводилось, имеются лишь краткие упоминания о последствиях существования колоний околоводных птиц на островах для видового разнообразия их флоры [Chepinoga et al., 2012], а также об уничтожении или изреживании растительности на колонизированных участках [Биоценозы... 1987].

Наряду с вышесказанным острова с их биотой - это важные объекты для теории и практики охраны природы. Последнее обстоятельство имеет особое значение в тех случаях, когда острова располагаются в пределах охраняемых территорий. К данному разряду относятся и острова Чивыркуйского залива, названные В. Н. Моложниковым [1974] по их числу Чивыркуйским семиостровьем. Специальных исследований растительного покрова Чивыркуйского семиостровья не проводилось. Некоторые краткие сведения разбросаны по работам более широкого плана [Моложников, 1974; Природа Забайкальского... 1990; Природопользование... 1990; Уникальные объекты... 1990; и др.] либо включены в обобщающие флористические сводки [Попов, Бусик, 1966; Флора Центральной Сибири, 1979; Флора Забайкальского... 1991; Аненхонов, Пыхалова, 2010; и др.]. Все имевшиеся ботанические сведения и гербарные материалы были собраны в ходе попутных визитов на острова, совершенных различными исследователями. В результате растительный покров этих островов оставался недостаточно изученным, лишь в 2018 г. были проведены целенаправленные ботанические изыскания [Бухарова и др., 2019]. В ходе этих работ также были посещены острова Чивыркуйского залива с колониями околоводных птиц — монгольской чайки (Larus (vegae) mongolicus (Sushkin, 1925)) и большого баклана (Phalacrocorax carbo (Linnaeus, 1758)). В данной статье представлены результаты обследования растительного покрова этих островов, населенных колониями околоводных птиц. 
О. А. Аненхонов, Е. В. Бухарова, А. А. Ананин. Состояние растительного покрова островов Чивыркуйского залива на Байкале в условиях влияния колоний околоводных птиц

Цель настоящей работы - выявление современного состояния растительного покрова трех островов Чивыркуйского залива, находящегося под влиянием орнитогенных факторов, а также его эколого-биологическая оценка.

\section{Район исследований}

Чивыркуйский залив расположен в северной половине оз. Байкал у его восточного побережья и входит в охраняемую территорию Забайкальского национального парка (ЗНП), который вместе Баргузинским государственным природным биосферным заповедником и Фролихинским государственным природным заказником с 2011 г. находится под управлением ФГБУ «Заповедное Подлеморье».

Семь островов Чивыркуйского залива разбросаны по его акватории, но в основном тяготеют к побережьям. Это Бакланий (Большой Бакланий), Лохматый (Большой) Кылтыгей, Голый (Малый) Кылтыгей, Покойницкий (Курбуликский) Камень, Елена, Белый Камень (Камешек), Коврижка (Копёшка) (рис. 1). Колонии околоводных птиц существуют на трех «срединных» островах: Голый Кылтыгей, Покойницкий Камень, Белый Камень. Из них только о-в Голый Кылтыгей сравнительно крупный, а два других очень маленькие (табл. 1).

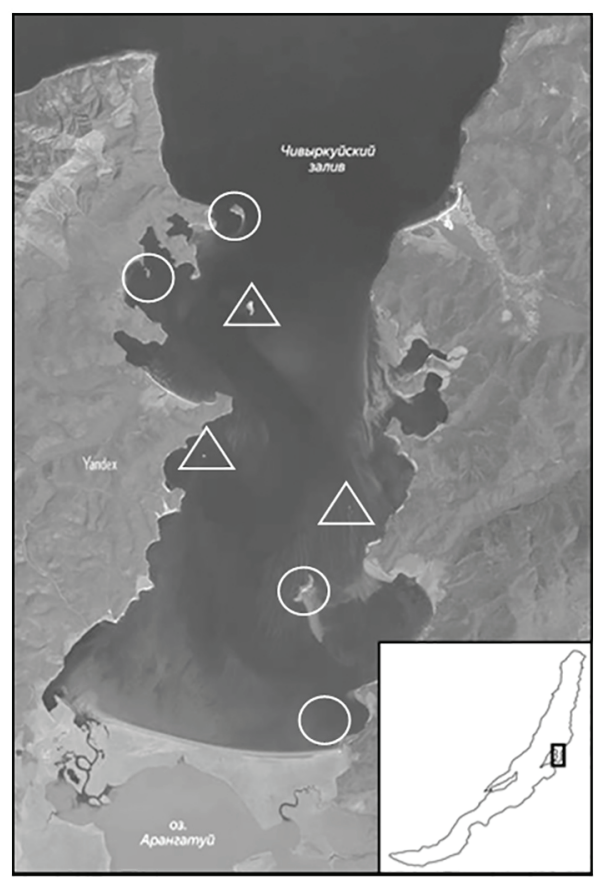

Puc. 1. Расположение островов Чивыркуйского залива на Байкале. Местонахождения островов, сверху вниз: кругами - без колоний птиц (Лохматый Кылтыгей, Елена, Бакланий, Коврижка); треугольниками - с колониями птиц (Голый Кылтыгей, Покойницкий Камень, Белый Камень)

О-в Голый Кылтыгей представляет собой вытянутое гористое возвышение, ориентированное, в общем, с севера на юг. Северные и восточные склоны образованы обрывистыми утесами, западные и юго-западные - более или менее ровные, круто наклонные, местами вогнутые и неглубоко рассечены ложбинами 
стока. Южную оконечность острова образует небольшой песчано-галечный террасовидный мыс, приподнятый над уровнем озера до 1-1,5 м, покрытый луговинами, кустарниками и несколькими деревьями кедра и лиственницы. Верхняя часть острова облесена, но в настоящее время лес находится на терминальной стадии отмирания, очевидно, в силу интоксикации пометом бакланов и чаек, создавших здесь крупную гнездовую колонию. Открытые участки склонов покрыты нитрофильно-рудеральными группировками либо степными сообществами, часто обедненного состава и иногда с рудеральными компонентами.

О-в Покойницкий Камень имеет форму, по контуру близкую к овальной. Его основную часть образует скальный массив, к которому с северо-запада «прислонена» террасовидная, слабо приподнятая над урезом воды, узкотреугольная в плане площадка. На этой площадке развиты высокопродуктивные нитрофильные рудерализованные луга с немногочисленными деревцами березы (Betula platyphylla Sukacz.), невысокими деревьями тополя (Populus laurifolia Ledeb.) и кустами ив (Salix spp.). Нитрофильные луговые сообщества сформированы и на склонах, где также присутствуют единичные стволы отмирающих кедров. Верхняя часть острова полностью лишена растительности из-за гнездовой колонии чаек и бакланов.

Лишенный растительности о-в Белый Камень представляет собой практически монолитную скалу продолговатой формы, склоны которой отвесно уходят в воду либо деформированы различными выступами и волноприбойными гротами. Растительность на острове отсутствует.

\section{Материалы и методы}

Обследование растительного покрова островов, населенных колониями околоводных птиц, проводилось в конце июня 2018 г. Для исследования островной флоры был использован маршрутный метод. Участки с отвесными скалами, уходящими в воду, ввиду крайней труднодоступности не обследовались. Скальные группировки на прибрежных скалах обследовались в пределах доступности в случае наличия полоски суши (валуны, галька) у основания скал, специальное снаряжение для скалолазания не использовалось. В ходе маршрутных обследований была сделана попытка охватить все основные типы растительных сообществ. В ходе маршрутов составлялись флористические списки, отбирались гербарные образцы.

Маршрутное обследование о-ва Голый Кылтыгей проходило с учетом доступности тех или иных участков и достаточности времени. Маршруты представляли собой полосы, в пределах которых движение осуществлялось более или менее зигзагообразно с боковой амплитудой до 10 м, и были заложены: 1) от южной оконечности острова и примерно до его середины вдоль гребня, затем спуск до середины западного склона и траверс до обрыва на северной оконечности; 2) вдоль береговой линии, начиная от южной оконечности острова и до скалистых обрывов у его северной оконечности; при этом обследовались и прилегающие к береговой террасе скалы, осыпи, ложбины стока, а также расположенные на террасе луговины и маленькие болотца. На о-ве Покойницкий Камень были обследованы все имеющиеся экотопы, за исключением высоких участков отвесных скал. На о-ве Голый Кылтыгей выполнено 8 (5 по $25 \mathrm{~m}^{2}, 1-30 \mathrm{~m}^{2}, 2$ по $\left.100 \mathrm{~m}^{2}\right)$, на о-ве Покойницкий Камень - 2 (по $100 \mathrm{~m}^{2}$ ) стандартных геоботанических описания растительных сообществ [Полевая геоботаника, 1964] с полным учетом флористического состава на площадках. В настоящей статье приводим лишь те описания, которые наиболее 
О. А. Аненхонов, Е. В. Бухарова, А. А. Ананин. Состояние растительного покрова островов Чивыркуйского залива на Байкале в условиях влияния колоний околоводных птиц

ясно отражают особенности влияния птичьих колоний на растительность. О-в Белый Камень был обследован нами лишь визуально (бинокль Navigator $12 \times 50$ ), дистанционно - с борта маломерного судна, в связи с невозможностью высадки на остров из-за отвесных скал и даже приближения к нему на расстояние менее чем 5 м из-за волнового прибоя.

Определение растений проводили по Флоре Сибири [1988-2003] и Определителю растений Бурятии [2001]. Поясно-зональные группы (ПЗГ) приняты по Л. И. Малышеву, Г. А. Пешковой [1984] и Г. А. Пешковой [2001]. Собранные гербарные образцы с островов Чивыркуйского залива (около 300 листов, включая 3 острова с колониями птиц) хранятся в Гербарии ИОЭБ СО РАН, г. Улан-Удэ (UUH). Номенклатура названий растений приводится по Конспекту флоры Азиатской России [2013].

\section{Результаты}

Из трех Чивыркуйских островов, населенных колониями околоводных птиц, выделяется о-в Голый Кылтыгей - наиболее крупный и высокий (табл. 1). Этот остров населен и наиболее крупной колонией птиц. В ней в период 2015-2018 гг. насчитывалось 3300-3500 гнездящихся пар бакланов (примерно 1800 - на деревьях и 1500 - на скальных обрывах) [Ананин, Овдин, Янкус, 2018], а монгольской чайки — в 2016 г. — около 50 гнезд, в 2017 - 220, в 2018 - 80 гнезд (А. А. Ананин, собственные наблюдения). Дополнительно к гнездящимся бакланам следует учитывать и негнездящуюся часть их популяции, которая для всего Чивыркуйского залива оценивается как не менее 2500-3000 особей [Ананин, Овдин, Янкус, 2018]. При этом колония оказывает прямое воздействие приблизительно на 1/3-1/4 площади острова в его наиболее приподнятой северо-восточной части, а также на обрывистых восточных и северо-западных склонах.

Таблица 1

Некоторые географические и биологические показатели островов Чивыркуйского залива

\begin{tabular}{|l|c|c|c|c|c|}
\hline Остров & $\begin{array}{c}\text { Площадь, } \\
\text { га }^{1}\end{array}$ & $\begin{array}{c}\text { Высота над } \\
\text { Байкалом, }\end{array} \mathbf{2}^{2}$ & $\begin{array}{c}\text { Расстояние } \\
\text { до берега, м }\end{array}$ & $\begin{array}{c}\text { Колонии } \\
\text { птиц }\end{array}$ & $\begin{array}{c}\text { Число видов } \\
\text { растений }^{3}\end{array}$ \\
\hline Бакланий & 19,2 & $15-40$ & 2170 & - & 176 \\
\hline $\begin{array}{l}\text { Лохматый } \\
\text { Кылтыгей }\end{array}$ & 14,8 & $50-80$ & 746 & - & 177 \\
\hline Голый Кылтыгей & 8,8 & $50-80$ & 2300 & + & 128 \\
\hline Елена & 2,3 & $12-15$ & 144 & - & 103 \\
\hline $\begin{array}{l}\text { Покойницкий } \\
\text { Камень }\end{array}$ & 0,8 & $20-25$ & 710 & + & 43 \\
\hline Коврижка & 0,2 & $8-12$ & 160 & - & 38 \\
\hline Белый Камень & 0,2 & $40-60$ & 1480 & + & 1 \\
\hline
\end{tabular}

Примечание: серой заливкой выделены острова, населенные колониями околоводных птиц.

${ }^{1}$ По «Пояснительная записка...», 2015.

${ }^{2}$ По В. Н. Моложникову [1974].

${ }^{3}$ Оригинальные данные [Бухарова и др., 2019]. 
Вдоль гребня острова располагаются лесные сообщества из лиственницы (Larix sp.) с примесью кедра сибирского (Pinus sibirica Du Tour) и осины (Populus tremula L.), в настоящее время - усохшие (рис. 3). Живые особи деревьев сохранились лишь по краю залесенного участка, но и их жизненность очень низка. На залесенной части острова поверхность почвы покрыта толстым слоем помета птиц, что заставляет считать токсический эффект причиной гибели древостоя в большей части лесного массива и угнетенного состояния оставшихся деревьев. Непосредственно под колонией гнездящихся на деревьях птиц травостой отсутствует. Лишь на периферии лесного массива развита мозаика бурьянистых группировок, расположенных как под пологом усохшего древостоя, так и на открытых участках между стволами деревьев. Эти группировки имеют размер от 1 до 10 м $^{2}$, перемежаются с участками с обнаженной поверхностью, покрытой пометом, монодоминантны, каждое пятно в мозаике сложено, как правило, лишь одним видом с проективным покрытием до 100 \%: Artemisia dracunculus L., A. vulgaris L., Calamagrostis epigeios (L.) Roth., Chenopodium album L.

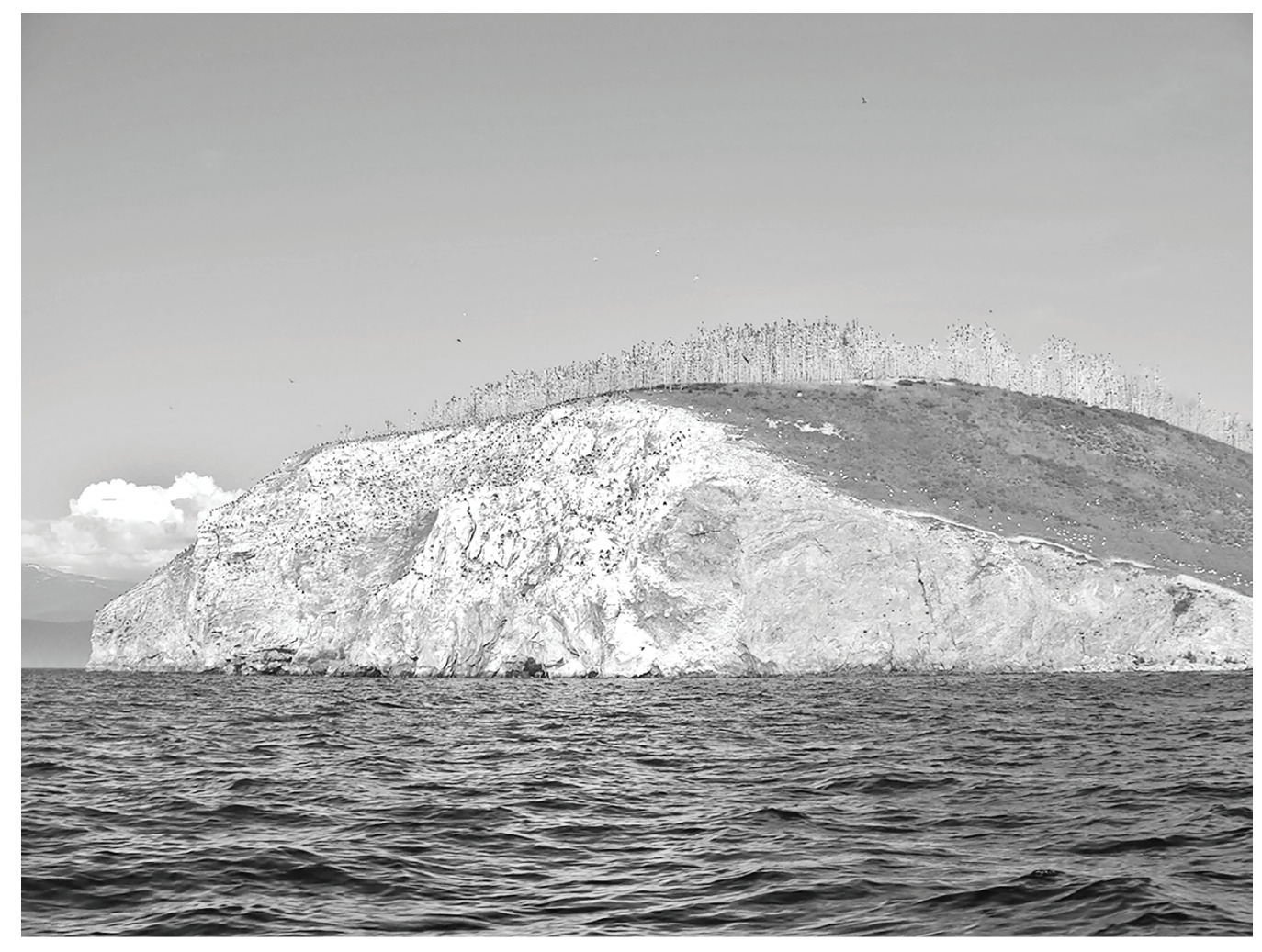

Puc. 2. Остров Голый Кылтыгей, вид на его северо-западную часть с запада. На вершине острова - усыхающий древостой, темные пятна - немногочисленные оставшиеся живые облиственные ветви в верхушечной части деревьев осины, а также бакланы, сидящие на ветвях. Россыпь темных пятен на обрыве - бакланы и их гнезда; белые пятна на покрытом травой остепненном склоне вдоль кромки обрыва - сидящие чайки. Фото: О. А. Аненхонов, 01.07.2018 
О. А. Аненхонов, Е. В. Бухарова, А. А. Ананин. Состояние растительного покрова островов Чивыркуйского залива на Байкале в условиях влияния колоний околоводных птиц

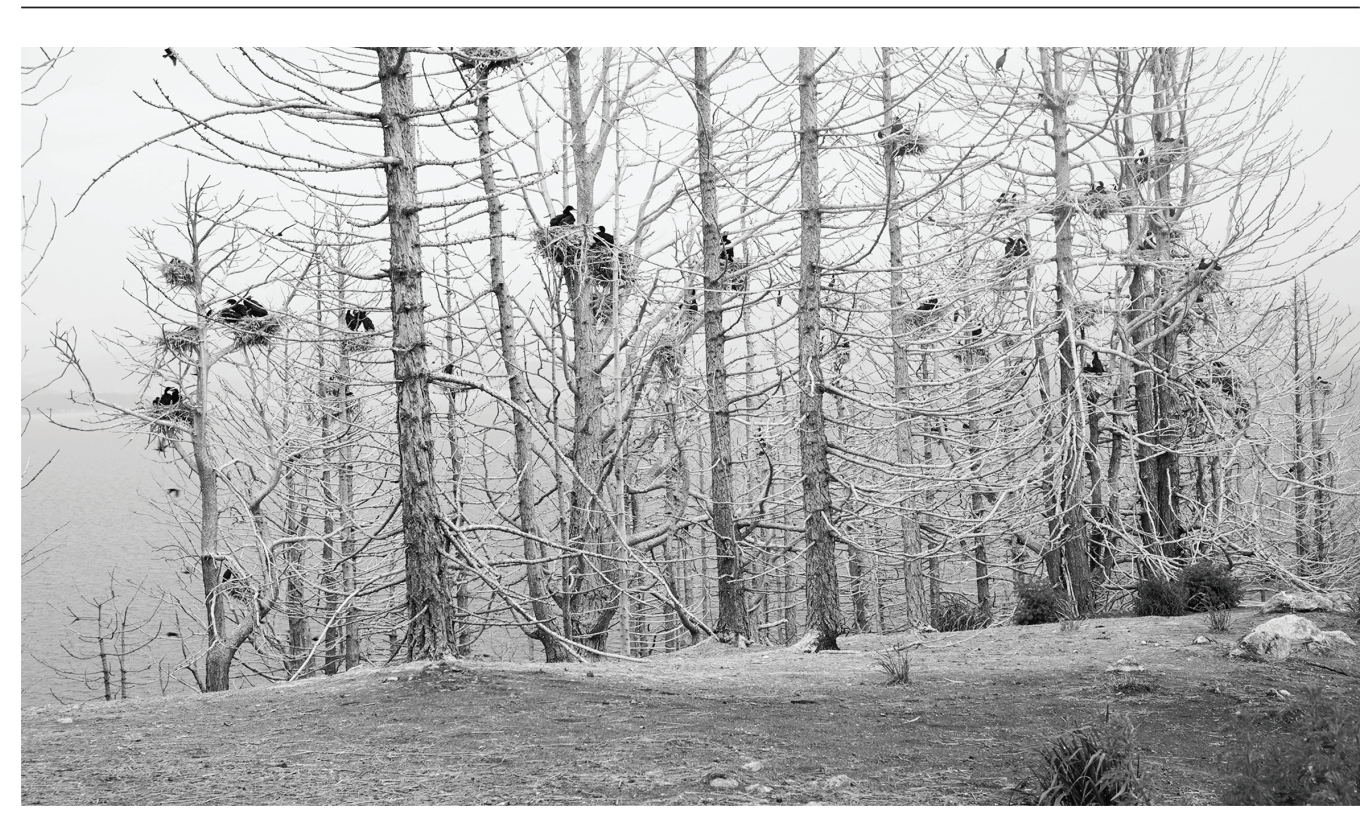

Puc. 3. Усохший лиственничник с гнездящимися бакланами в вершинной части о-ва Голый Кылтыгей. Травяные куртины сложены Calamagrostis epigeios (L.) Roth., Artemisia dracunculus L., A. vulgaris L. Фото: Е. В. Бухарова, 01.07.2018

Контур лиственничника с запада окаймляется зарослями C. epigeios, местами с рощицами осины, которые также подвержены орнитогенной интоксикации почв. Вследствие этого особи осины сильно угнетены и в их кронах наблюдаются лишь отдельные пучки облиственных веточек, а часть особей отмерла. В травяном покрове орнитогенная трансформация выражается в господстве C. epigeios, образующем почти сплошные заросли, что нехарактерно для естественных лесных сообществ. При этом видовой состав в целом представлен растениями индигенной, преимущественно лесной флоры, а типичный рудерал лишь $1-C h$ album, причем с небольшим покрытием (табл. 2).

Бо́льшая часть склона западной экспозиции покрыта мозаикой степных сообществ - житняковых, бурачковых, кострецовых, ледебурополынных, которые располагаются в транзитной позиции катены по отношению к птичьей колонии (находится в элювиальной позиции) и, очевидно, подвержены ее косвенному влиянию за счет гравитационного и ветрового перемещения птичьего помета и продуктов его распада, как со стоковыми водами, так и в виде пылеватых частиц. Мозаичность сложения, обедненный видовой состав сообществ создают облик растительного покрова, характерный для нарушенных территорий. В качестве примера приведем описание петрофитного степного сообщества (табл. 3).

Западное побережье и южный мыс острова образованы песчано-галечной террасой, невысоко (на 1-1,5 м) приподнятой над уровнем Байкала. С ее тыльной стороны в понижениях рельефа развиты маленькие болотца; повышенные участки террасы заняты травяными луговинами, перемежающимися с галечниками, на которых растения встречаются лишь разрозненно. 
Состав и проективное покрытие (ПП) видов растений в осиннике вейниковом на о-ве Голый Кылтыгей*

(Чивыркуйский залив, Северный Байкал)

\begin{tabular}{|c|c|c|c|}
\hline № & Вид & ПП, \% & ПЗГ \\
\hline \multicolumn{4}{|c|}{ Древесный ярус: ПП $-5 \%, \mathrm{~h}-5-8 \mathrm{~m}, \mathrm{~d}_{\mathrm{cp.}}-10 \mathrm{~cm}, \mathrm{~d}_{\max }-17$ см } \\
\hline 1 & Populus tremula $\mathrm{L}$. & 5 & ПБ \\
\hline 2 & Pinus sibirica Du Tour & + & TX \\
\hline \multicolumn{4}{|c|}{ Травяной ярус: ПП - 80\%, h- 75 см } \\
\hline 3 & Calamagrostis epigeios (L.) Roth & 75 & $\mathrm{CX}$ \\
\hline 4 & Carex macroura Meinsh. & 1 & $\mathrm{CX}$ \\
\hline 5 & Dracocephalum nutans L. & 1 & ЛС \\
\hline 6 & Myosotis imitata Serg. & 1 & ЛС \\
\hline 7 & Poa sibirica Roshev. & 1 & TX \\
\hline 8 & Bromopsis austrosibirica Peschkova & + & $\mathrm{CX}$ \\
\hline 9 & Chamaenerion angustifolium (L.) Scop. & + & $\mathrm{CX}$ \\
\hline 10 & Chenopodium album $\mathrm{L}$. & + & $\mathrm{P}$ \\
\hline 11 & Euphorbia borealis Baikov & + & $\mathrm{CX}$ \\
\hline 12 & Lathyrus humilis (Ser.) Spreng. & + & $\mathrm{CX}$ \\
\hline 13 & Poa krylovii Reverd. & + & $\Gamma \mathrm{C}$ \\
\hline 14 & Scutellaria scordiifolia Fisch. ex Schrank & + & $\mathrm{CC}$ \\
\hline 15 & Thalictrum minus L. & + & $\mathrm{CX}$ \\
\hline 16 & Thalictrum foetidum $\mathrm{L}$. & + & $\Gamma \mathrm{C}$ \\
\hline 17 & Artemisia dracunculus L. & $\mathrm{r}$ & ЛС \\
\hline 18 & Cotoneaster melanocarpus Fisch. ex Blytt. & $\mathrm{r}$ & $\mathrm{CX}$ \\
\hline 19 & Galium boreale L. & $\mathrm{r}$ & ЛС \\
\hline 20 & Pleurospermum uralense Hoffm. & $\mathrm{r}$ & $\mathrm{CX}$ \\
\hline 21 & Rosa acicularis Lindl. & $\mathrm{r}$ & $\mathrm{CX}$ \\
\hline 22 & Valeriana transjenisensis Kreyer & $\mathrm{r}$ & $\mathrm{CX}$ \\
\hline 23 & Vicia nervata Sipl. & $\mathrm{r}$ & ЛС \\
\hline
\end{tabular}

* У юго-восточной оконечности о-ва Голый Кылтыгей, 5346’40.4” с. ш., Е10905’33.6” в. Д., высота над ур. м. - 443 м, верхняя (привершинная) часть склона, экспозиция - запад $\left(240^{\circ}\right)$, уклон - $14^{\circ}, \mathrm{S}$ описания - $100 \mathrm{~m}^{2}, 30.06 .2018$. О. А. Аненхонов

Примечание: "+" - ПП < 1\%; "r" - единичное растение с ПП $<1 \%$.

Обозначения ПЗГ: ПБ - пребореальная; СX — светлохвойно-лесная; ТХ - темнохвойнолесная; ЛС - лесостепная; ГС — горностепная; СС - собственно степная; Р рудеральная. 
О. А. Аненхонов, Е. В. Бухарова, А. А. Ананин. Состояние растительного покрова островов Чивыркуйского залива на Байкале в условиях влияния колоний околоводных птиц

Таблицьа 3

Состав и проективное покрытие (ПП) видов растений

в петрофитном бурачковом степном сообществе на о-ве Голый Кылтыгей*

(Чивыркуйский залив, Северный Байкал)

\begin{tabular}{|c|c|c|c|}
\hline № & Вид & ПП, \% & ПЗГ \\
\hline \multicolumn{4}{|c|}{ Травяной ярус: ПП $-45 \%, \mathrm{~h}_{1}-35$ см, $\mathrm{h}_{2}-10$ см } \\
\hline 1 & Alyssum obovatum (C.A. Mey.) Turcz. & 40 & $\Gamma \mathrm{C}$ \\
\hline 2 & Artemisia ledebourinana Bess. & 4 & $\mathrm{CC}$ \\
\hline 3 & Agropyron cristatum (L.) Beauv. & 2 & $\mathrm{CC}$ \\
\hline 4 & Lappula consanguinea (Fisch. et C.A. Mey.) Guerke & 1 & ЛС \\
\hline 5 & Calamagrostis epigeios (L.) Roth & + & $\mathrm{CX}$ \\
\hline 6 & Chenopodium album $\mathrm{L}$. & + & $P$ \\
\hline 7 & Dracocephalum nutans L. & + & ЛС \\
\hline 8 & Orostachys spinosa (L.) C.A. Mey. & + & $\Gamma \mathrm{C}$ \\
\hline 9 & Tephroseris integrifolia (L.) Holub & + & ЛС \\
\hline 10 & Vicia nervata Sipl. & + & ЛС \\
\hline 11 & Thymus baicalensis Serg. & + & $\mathrm{CC}$ \\
\hline 12 & Allium strictum Schrader & $\mathrm{r}$ & ЛС \\
\hline 13 & Festuca ovina L. & $\mathrm{r}$ & $\mathrm{CX}$ \\
\hline 14 & Koeleria cristata (L.) Pers. & $\mathrm{r}$ & ЛС \\
\hline
\end{tabular}

* На западном склоне о-ва Голый Кылтыгей, поверхность - супесь с дресвой, выступают плосковатые камни; 5346’44.4” с. ш., 10905'29.4” в. д., высота над ур. м. - 440 м, средняя часть склона, экспозиция - юго-западная $\left(200^{\circ}\right)$, уклон $-30^{\circ}$, S описания -25 м $^{2}$, 30.06.2018. О. А. Аненхонов

Примечание: "+" - ПП $<1 \%$; "r" - единичное растение с ПП $<1 \%$.

Обозначения ПЗГ: ЛС - лесостепная; ГС - горностепная; СС - собственно степная; СХ - светлохвойно-лесная; Р — рудеральная.

Эти сообщества, находясь в аккумулятивной части катены, по всей видимости, подвержены нитрификации за счет привноса биогенных элементов из колонии птиц. Об этом свидетельствует, например, наличие типичного нитрофила - крапивы (Urtica dioica L.), которая на отдельных участках принимает существенное участие в составе травостоя (с ПП до 20\%). Однако в целом, на наш взгляд, орнитогенная трансформация растительных сообществ террасы незначительна.

Восточный и северный склоны и побережье о-ва Голый Кылтыгей представляют собой отвесные скалы и крутые склоны, на которых сомкнутая растительность не развита, а на выположенных и не слишком круто наклонных участках (полки, уступы и т. п.) она отсутствует вследствие жизнедеятельности птиц.

Остров Покойницкий Камень практически весь заселен колонией бакланов и чаек. Ежегодно на острове насчитывается 80-120 пар гнездящихся бакланов, 
а монгольской чайки - 160-300 гнезд (А. А. Ананин, собственные наблюдения). Особенно высокая плотность гнездования наблюдается на вершине и в привершинной части острова, в результате чего растительный покров здесь отсутствует. На склоне сформирована мозаика травяных сообществ из Leymus littoralis (Griseb.) Peschkova и A. dracunculus, среди которых местами гнездятся чайки. Сообщества трансформированы, травостой подвергается вытаптыванию птицами, степень трансформации нарастает вверх по склону, проективное покрытие постепенно уменьшается, и в привершинной части травостой представляет собой мозаику из голых и заросших травой участков. На террасе имеются одно сильно угнетенное высокое и несколько невысоких молодых деревьев березы. Травостой здесь почти сплошной, лишь с протоптанными тропинками, в нем господствуют Calamagrostis langsdorffii (Link) Trin. и Equisetum pratense Ehrh. Орнитогенные изменения проявляются в обедненности видового состава, повышенной мощности особей растений, присутствии нитрофильных растений - U. dioica и Lamium album L. В целом состав сообщества — это лесо-луговые и лугово-болотные растения (табл. 4).

Таблииа 4

Состав и проективное покрытие (ПП) видов растений разнотравно-злакового луга на о-ве Покойницкий (Курбуликский) камень *

(Чивыркуйский залив, Северный Байкал)

\begin{tabular}{|c|c|c|c|}
\hline № & Вид & ПП, \% & ПЗГ \\
\hline \multicolumn{4}{|c|}{ Древесный ярус: ПП $-4 \%, \mathrm{~h}-3-7 \mathrm{M}, \mathrm{d}_{\mathrm{cp.}}-5 \mathrm{~cm}, \mathrm{~d}_{\text {max. }}-20$ см } \\
\hline 1 & Betula platyphylla Sukacz. & 4 & ПБ \\
\hline \multicolumn{4}{|c|}{ Травяной ярус: ПП $-80 \%, \mathrm{~h}_{1}-100 \mathrm{~cm}, \mathrm{~h}_{2}-40 \mathrm{~cm}$} \\
\hline 2 & Calamagrostis langsdorffii (Link) Trin. & 45 & ЛГ \\
\hline 3 & Equisetum pratense Ehrh. & 20 & $\mathrm{CX}$ \\
\hline 4 & Poa pratensis L. & 4 & ЛГ \\
\hline 5 & Filipendula ulmaria (L.) Maxim. & 3 & $\mathrm{CX}$ \\
\hline 6 & Urtica dioica $\mathrm{L}$. & 3 & $\mathrm{P}$ \\
\hline 7 & Rubus matsumuranus H. Lav. \& Vaniot & 2 & $\mathrm{CX}$ \\
\hline 8 & Veronica longifolia $\mathrm{L}$. & 2 & ЛГ \\
\hline 9 & Anemonidium dichotomum (L.) Holub & 1 & ЛГ \\
\hline 10 & Lamium album L. & 1 & $\mathrm{CX}$ \\
\hline
\end{tabular}

* На прибрежной террасе северо-западной части о-ва Покойницкий Камень. Поверхность кочковатая, с валунами и гнездами чаек. S описания - 100 м2, 29.06.2018. Е. В. Бухарова, Т. Д. Пыхалова.

Обозначения ПЗГ: ПБ — пребореальная; СХ — светлохвойно-лесная; ЛГ — луговая; Р — рудеральная. 
О. А. Аненхонов, Е. В. Бухарова, А. А. Ананин. Состояние растительного покрова островов Чивыркуйского залива на Байкале в условиях влияния колоний околоводных птиц

На о-ве Белый Камень в период 2016-2019 гг. ежегодно гнездились 190-240 пар бакланов, а гнезд чаек зарегистрировано не было (А. А. Ананин, собственные наблюдения). Как отмечалось выше, растительность на острове отсутствует. Здесь в расщелинах отвесных скал отмечены лишь две особи полыни, относящиеся, предположительно, к Artemisia mongolica (Besser) Fisch. ex Nakai (собрать растения для их точного определения было невозможно ввиду того, что они обитают на отвесных скалах высоко над урезом воды). Эти особи закрепились в расщелинах на скалистых обрывах с западной и восточной части острова и, по всей видимости, выживают здесь благодаря отсутствию вытаптывания птицами.

\section{Обсуждение}

Влияние бакланов и монгольских чаек на растительность островов с их гнездовыми поселениями определяется в первую очередь внесением такой большой массы ${ }^{1}$ органики (экскрементов) - соединений азота (а также и других элементов), в которой она оказывает токсический эффект на индигенную растительность. Второй фактор - это механическое воздействие - вытаптывание травяной растительности птицами в местах расположения их наземных гнезд. Бакланы дополнительно оказывают механическое воздействие на древесные растения, располагая свои гнезда в их кроне. При этом птицы обламывают часть веток для устройства и обновления своих гнезд.

Известно, что орнитогенные факторы оказывают существенное воздействие на растительный покров морских островов, вызывая обеднение флоры, трансформацию ее состава, а также состава и структуры растительных сообществ [Хорева, 2003; Хорева, Мочалова, 2009]. В то же время имеются мнения о том, что колонии птиц могут вносить вклад в обогащение флоры островов, как, например, на о-ве Фуругельма в Японском море [Чубарь, 2005]. Несомненно, что на растительный покров трех островов Чивыркуйского залива (Белый Камень, Покойницкий Камень, Голый Кылтыгей) орнитогенные факторы оказывают значительное влияние. В частности, можно говорить о тенденции снижения числа видов на этих островах, связанной именно с орнитогенными факторами, однако ввиду слишком малой выборки (в архипелаге лишь 7 островов, из которых 3 с колониями птиц) статистическое подтверждение этому дать невозможно. В качестве примера указанной тенденции отметим, что площадь о-ва Покойницкий Камень больше в 4 раза, чем у о-ва Коврижка, а видов на нем выявлено лишь на 5 больше. Менее показательны, но соответствуют этой тенденции показатели о-вов Голый Кылтыгей и Елена: соотношение их площадей равно 3,8, а числа видов - 1,2 (табл. 1). При этом частично противодействующим обеднению флоры обстоятельством является то, что, в отличие от о-вов Белый Камень и Покойницкий Камень, на о-ве Голый Кылтыгей птичья колония оккупирует и оказывает разрушительное воздействие лишь на около 1/3-1/4 его площади, а на остальной территории ее влияние существенно ослаблено.

В связи с тем, что влияние птичьих колоний на растительный покров носит в основном деструктивный характер, интересно рассмотреть, способствует ли оно

\footnotetext{
${ }^{1}$ Количественных данных об объеме поступления орнитогенных соединений и их содержании в почвогрунтах островов не имеется.
} 
адвентизации растительного покрова. Несмотря на недостаток подробных сведений об этом процессе, даже краткие посещения в прошлом позволяли специалистам делать заключения о сохранности экосистем в коренном состоянии или же близком к нему. Вместе с тем на островах все же отмечались среди прочих адвентивные виды, но без подробной информации об их местообитаниях. Можно предполагать, что таковыми были участки с пониженной или отсутствующей конкуренцией со стороны индигенных видов: прибрежно-водные - песчаные и галечные пляжи, каменистые прибрежья; а также осыпные участки крутых склонов. То есть это участки, предоставляющие возможность спонтанно расселяющимся (анемохорно, гидрохорно или зоохорно) адвентивным растениям вселяться на острова. Подчеркнем, что никаких данных, специально акцентированных на адвентах, ранее не имелось. Однако, судя по результатам наших флористических исследований [Бухарова и др., 2019], число антропофитов на островах невелико. В условиях воздействия птичьих колоний коренные растительные сообщества деградируют, вплоть до полного исчезновения, а некоторые растения-нитрофилы, как из состава индигенной флоры, так и адвентивные, приобретают конкурентное преимущество, при этом некоторые из них образуют густые заросли или куртины на участках, обильно удобренных органикой в результате жизнедеятельности колоний птиц [Мочалова, Хорева, 2009; Ellis, 2005; Zolkos et al., 2013]. В результате этого на Чивыркуйских островах адвентизация выражается в повышении фитоценотической роли некоторых индигенных, а также отдельных заносных видов, но не в кардинальном увеличении числа рудералов.

Токсический эффект помета является наиболее мощным из видов воздействий птичьих колоний на растительность [Ellis, 2005; Natusch et al., 2017] и наблюдается на всех трех Чивыркуйских островах, колонизированных птицами. Вытаптывание травяной растительности и повреждение деревьев в местах расположения колоний наблюдается на островах Голый Кылтыгей и Покойницкий Камень. Совместное воздействие этих факторов привело к уничтожению растительности на густонаселенных участках колоний и ее фрагментации на малонаселенных участках и периферии колоний.

На Чивыркуйских островах наиболее обильно разрастающимися по соседству с колониями видами являются Ch. album, Chelidonium majus L., U. dioica, A. vulgaris, A. dracunculus, C. langsdorffi, L. littoralis. При этом первые 4 вида считаются типичными нитрофилами. Из остальных в качестве обычных и мощно развивающихся рядом с колониями птиц отмечены C. langsdorffi [Мочалова, Хорева, 2009; Хорева, Мочалова, 2009], а также приморские виды рода Leymus: L. mollis (Trin.) Pilg. [Мочалова, Хорева, 2009; Хорева, Мочалова, 2009] и L. arenarius (L.) Hochst. [Бреслина, 1987]. Вероятно, некоторые конкурентные преимущества при умеренном обогащении почвы нитратами получают также отдельные типично степные виды: Agropyron distichum (Georgi) Peschkova, Alyssum lenense Adams, A. obovatum (C. A. Meyer) Turcz., Koeleria cristata (L.) Pers., и некоторые другие. Они встречаются с повышенным обилием в составе растительности остепненного склона на о-ве Голый Кылтыгей. При отсутствии явных причин для экотопологической гетерогенности растительности, как и отсутствии видимых следов антропогенных 
О. А. Аненхонов, Е. В. Бухарова, А. А. Ананин. Состояние растительного покрова островов Чивыркуйского залива на Байкале в условиях влияния колоний околоводных птиц

нарушений, растительность этого склона имеет мозаичный характер, и вышеупомянутые степные виды выступают доминантами на отдельных участках склона. Здесь на площади описания выявлено всего лишь 14 видов сосудистых растений (табл. 3), что может быть косвенным признаком нестабильного сообщества. Единственной видимой причиной мозаичности и низкой видовой насыщенности растительности остепненного склона представляется влияние птичьей колонии, оккупирующей гребень скалы острова. Расположенные ниже колонии растительные сообщества находятся в транзитном положении катены и испытывают дестабилизирующее влияние орнитогенных органических соединений и продуктов их распада, поступающих сюда вследствие гравитационного сноса.

Существование гнездовых птичьих колоний на островах не было постоянным (как на о-ве Белый Камень), либо был период (в отсутствие баклана на Байкале) их существенно более низкой численности по сравнению с наблюдающейся в настоящее время (Голый Кылтыгей и Покойницкий Камень). Бурное развитие птичьих колоний особенно в 2010-2015 гг. с возвращением баклана на Байкал [Ананин, Овдин, Янкус, 2018] привело к практически необратимым последствиям для растительного покрова, сформировавшегося в предшествовавший период. Фактически на о-вах Голый Кылтыгей и Покойницкий Камень орнитогенные факторы привели к значительной трансформации растительного мира, по крайней мере на значительной части поверхности этих островов. Тем не менее, как отметили М. Е. Овдин и др. [2018], усыхание деревьев, выросших на о-ве Голый Кылтыгей за 50 лет отсутствия баклана на Байкале, приводит растительность в исходное состояние, имевшее место до исчезновения здесь гнездовой колонии.

В целом воздействие колоний птиц на Чивыркуйском семиостровье аналогично влиянию птичьих базаров на экосистемы морских островов [Бреслина, 1987; Мочалова, Хорева, Зеленская, 2005; Мочалова, Хорева, 2009; Хорева, Мочалова, 2009; Ellis, 2005; и др.].

Отметим, что популяция баклана на Байкале существовала издавна [Гусев, 1980] и его появление здесь в последние годы можно рассматривать в качестве элемента восстановления естественного состояния местной орнитофауны. В связи с тем, что рост численности популяции баклана на оз. Байкал вызывает негативное отношение со стороны «конкурирующих» рыбозаготовителей (как организаций, так и частных лиц), необходимо подчеркнуть, что трансформация растительного покрова на островах, колонизированных околоводными птицами (чайками, бакланами), не является свидетельством негативных последствий, а находится в ряду естественных процессов, сопровождающих динамику природных экосистем и их компонентов.

\section{Заключение}

Таким образом, современное состояние растительного покрова трех островов Чивыркуйского залива, населенных колониями околоводных птиц, характеризуется явной трансформацией. Она проявляется в обеднении состава флоры, повышенной мозаичности растительности, отмирании деревьев и целых лесных сообществ, высоком обилии отдельных видов растений (нитрофилов) в сообще- 
ствах. Эти тенденции прослеживаются даже на о-ве Голый Кылтыгей - наиболее крупном из этих островов, где колония птиц занимает приблизительно 1/4-1/3 его площади. В этом случае влияние колонии птиц на растительный покров реализуется за счет ее расположения в элювиальной части катены, вследствие чего транзитные и аккумулятивные местообитания оказываются вовлечены в биогеохимические процессы, обусловленные жизнедеятельностью птиц. В результате влияния орнитогенных факторов наблюдается адвентизация растительности за счет повышения фитоценотической роли некоторых заносных видов. При этом повышения адвентизации флоры не обнаружено. Последствия влияния орнитогенных факторов на растительный покров трех островов Чивыркуйского семиостровья в целом не отличаются от таковых на морских островах. Состояние растительного покрова островов, колонизированных птицами, представляет собой естественное явление, и наблюдающаяся деградация части растительных сообществ (особенно лесных) связана с ростом численности баклана, что отражает возвращение его популяции к состоянию до 1960-х гг. С учетом этого с эколого-биологической точки зрения есть основания считать, что процессы трансформации растительного покрова не следует расценивать как негативные.

Благодарности: авторы выражают благодарность Администрации «Заповедного Подлеморья» за организачионную поддержку проведенных работ, а также лично участковому инспектору Ю. А. Гороховскому, сопровождавшему нас в экспедииии. Работа выполнена при поддержке гранта РФФИ 18-45-030026. Работа О. А. Аненхонова проводилась частично в рамках проекта № АAАAА17-117011810036-3. Работа А. А. Ананина проведена в рамках бюджетного проекта № АAАA-A17-117011810035-6. Авторы признательны канд. биол. наук Т. Д. Пьхаловой, принявшей участие в полевых исследованиях и в определении части гербарных материалов, собранных на островах Чивыркуйского залива.

\section{Литература}

1. Ананин А. А., Овдин М. Е., Янкус Г. А. Динамика численности большого баклана на Северном Байкале // Современные проблемы орнитологии Сибири и Центральной Азии: материалы VI Международной орнитологической конференции. Иркутск: ИНЦХТ, 2018. C. $17-21$.

2. Аненхонов О. А., Пыхалова Т. Д. Конспект флоры сосудистых растений Забайкальского национального парка. Улан-Удэ: Изд-во БНЦ СО РАН, 2010. 228 с.

3. Биоценозы островов пролива Малое Море на Байкале / под ред. Н. Г. Скрябина. Иркутск: Изд-во Иркут. ун-та, 1987. 184 с.

4. Бреслина И. П. Растения и водоплавающие птицы морских островов Кольской Субарктики. Л.: Наука, 1987. 200 с.

5. Бухарова Е. В., Аненхонов О. А., Бадмаева Н. К., Пыхалова Т. Д., Бурдуковский А. И., Лужкова Н. М. Аннотированный список флоры островов Чивыркуйского залива (Забайкальский национальный парк) // Природные комплексы Северо-Восточного Прибайкалья: труды Баргузинского государственного природного биосферного заповедника. Улан-Удэ: Изд-во БНЦ СО РАН, 2019. Вып. 11. С. 154-182. DOI 10/31554/978-5-7925-0575-9-11-2019$154-182$.

6. Гусев О. К. Большой баклан на Байкале // Охота и охотничье хозяйство. 1980. № 3. С. 14-17; № 4. С. 14-16. 
О. А. Аненхонов, Е. В. Бухарова, А. А. Ананин. Состояние растительного покрова островов Чивыркуйского залива на Байкале в условиях влияния колоний околоводных птиц

7. Иванов А. Н., Булочникова А. С., Романенко Ф. А. Скопления морских колониальных птиц как рельефообразуюший фактор // Геоморфология. 2010. № 1. С. 7-15.

8. Конспект флоры Азиатской России: сосудистые растения / под ред. К. С. Байкова. Новосибирск: Изд-во СО РАН, 2012. 640 с.

9. Малышев Л. И., Пешкова Г. А. Особенности и генезис флоры Сибири (Предбайкалье и Забайкалье). Новосибирск: Наука, 1984. 264 с.

10. Моложников В. Н. Полуостров Святой Нос и Чивыркуйское семиостровье (состояние экосистем и вопросы охраны их животных компонентов) // Природа Байкала. Л., 1974. C. 257-271.

11. Мочалова О. А., Хорева М. Г., Зеленская Л. А. Растительный покров в колониях топорков (Lunda cirrhata) на островах Северной Пацифики // Биология и охрана птиц Камчатки. Москва: ЦОДП, 2005. Вып. 7. С. 107-115.

12. Мочалова О. А., Хорева М. Г. Флора и растительность о. Матыкиль (Охотское море), их особенности в связи с воздействием морских колониальных птиц // Вестник СВНЦ ДВО РАН. 2009. № 4. С. 35-47.

13. Овдин М. Е., Янкус Г. А., Ананин А. А. Северобайкальская и баргузинская группировки большого баклана Phalacrocorax carbo в 2017 г. на Байкале // Байкальский зоологический журнал. 2018. № 2 (23). С. 57-60.

14. Определитель растений Бурятии / под ред. О. А. Аненхонова. Улан-Удэ: Республиканская типография, 2001. 672 с.

15. Пешкова Г. А. Флорогенетический анализ степной флоры гор Южной Сибири. Новосибирск: Наука, 2001. 192 с.

16. Попов М. Г., Бусик В. В. Конспект флоры побережий озера Байкал. М.-Л.: Наука, 1966. 215 c.

17. Пояснительная записка о результатах проектирования мероприятий по охране, защите и воспроизводству лесов на территории лесничества «Забайкальский национальный парк» / ООО НПП «Компьютерные технологии». Воронеж, 2015. 103 с.

18. Природа Забайкальского национального парка / А. Б. Иметхенов, Т. Г. Бойков, Ц. Х. Цыбжитов, Б. О. Юмов, С. А. Матвейчук. Улан-Удэ: Изд-во БНЦ СО АН СССР, 1990. $192 \mathrm{c}$.

19. Природопользование и охрана среды в бассейне Байкала / А. В. Мартынов, С. В. Рященко, А. В. Белов и др. Новосибирск: Наука, 1990. 224 с.

20. Уникальные объекты живой природы бассейна Байкала / А. С. Плешанов, Л. В. Бардунов, Т. В. Макрый и др. Новосибирск: Наука, 1990. 224 с.

21. Флора Забайкальского природного национального парка / Т. Г. Бойков, О. А. Аненхонов, Т. Д. Пыхалова, Ю. Д. Харитонов, И. Р. Сэкулич, О. В. Данилова, М. Б. Беркович. Улан-Удэ: Изд-во БНЦ СО АН СССР, 1991. 138 с.

22. Флора Сибири: в 14 т. / под ред. И. М. Красноборова, Л. И. Малышева, Г. А. Пешковой [и др.]. Новосибирск: Наука, 1988-2003.

23. Флора Центральной Сибири: в 2 т. / под ред. Л. И. Малышева, Г. А. Пешковой. Новосибирск: Наука, 1979.

24. Хорева М. Г. Флора островов Северной Охотии. Магадан: ИБПС ДВО РАН, 2003. $173 \mathrm{c}$.

25. Хорева М. Г., Мочалова О. А. Растения и птицы на берегах Охотского моря: равновесие, кризис, адаптации // Сибирский экологический журнал. 2009. № 1. С. 119-125.

26. Чубарь Е. А. Итоги инвентаризации флоры островов Дальневосточного государственного морского заповедника // Ботанический журнал. 2005. Т. 90, № 3. С. 360-377. 
27. Anderson D. J., Hodum P. J. Predator behavior favors clumped nesting in an oceanic seabird // Ecology. 1993. Vol. 74. P. 2462-2464.

28. Chepinoga V. V., Zverev V. E., Zvereva E. L., Kozlov V. K. Vascular plants on the islands and peninsulas of Maloe More (Lake Baikal): patterns of diversity and species turnover // Boreal Environment Research. 2012. Vol. 17. P. 219-236.

29. Ellis C. E. Marine birds on land: a review of plant biomass, species richness, and community composition in seabird colonies // Plant Ecology. 2005. Vol. 181. P. 227-241. DOI 10.1007/s11258-005-7147-y.

30. Ishida A. Effects of the common cormorant, Phalacrocorax carbo, on evergreen forests in two nest sites at Lake Biwa, Japan // Ecological Research. 1996. Vol. 11. P. 193-200.

31. MacArthur R. H., Wilson E. O. The theory of island biogeography. Princeton: Princeton University Press, 1967. 203 p.

32. Natusch D. J. D., Lyons J. A., Shine R. Safety first: terrestrial predators drive selection of highly specific nesting sites in colonial-breeding birds // Journal of Avian Biology. 2017. Vol. 48. P. 1104-1113. doi: 10.1111/jav.01380.

33. Natusch D. J. D., Lyons J. A., Brown G. P., Shine R. Biotic interactions mediate the influence of bird colonies on vegetation and soil chemistry at aggregation sites // Ecology. 2017. Vol. 98 (2). P. 382-392.

34. Oro D., Ruxton G. D. The formation and growth of seabird colonies: Audouin's gull as a case study // Journal of Animal Ecology. 2001. Vol. 70. P. 527-535.

35. Zolkos K., Meissner W., Olszewski T. S., Remisievicz M. Changes in khasi pine (Pinus kesiya Royle ex Gordon) tree stands affected by dimorphic egret Egretta dimorpha colony at Madagaskar // African Journal of Ecology. 2013. Vol. 51. P. 319-324. doi: 10.1111/aje.12038.

\section{CURRENT STATE OF VEGETATION COVER}

IN THE ISLANDS OF CHIVYRKUY BAY (LAKE BAIKAL)

UNDER THE INFLUENCE OF SEMIAQUATIC BIRD COLONIES

O. A. Anenkhonov, E. V. Bukharova, A. A. Ananin

Oleg A. Anenkhonov

Dr. Sci. (Biol.)

Institute of General and Experimental Biology SB RAS

6 Sakhyanovoy St., Ulan-Ude 670047, Russia

anen@yandex.ru

Evgeniya V. Bukharova

Cand. Sci. (Biol.)

Federal State Budgetary Institution "Preserved Podlemorye"

7 Lenina St., Ust-Barguzin 7671623, Russia

darakna@mail.ru

Alexander A. Ananin

Dr. Sci. (Biol.)

Federal State Budgetary Institution "Preserved Podlemorye"

7 Lenina St., Ust-Barguzin 7671623, Russia

Institute of General and Experimental Biology SB RAS

6 Sakhyanovoy St., Ulan-Ude 670047, Russia

a_ananin@mail.ru 
О. А. Аненхонов, Е. В. Бухарова, А. А. Ананин. Состояние растительного покрова островов Чивыркуйского залива на Байкале в условиях влияния колоний околоводных птиц

Abstract. Semiaquatic bird colonies influence strongly the vegetation cover of the islands. There are not many islands occupied by altricial birds in Lake Baikal. We have studied the vegetation cover of three islands of Chivyrkuy Bay (Northern Baikal area): Goly Kyltygey, Pokoynitzkiy Kamen, Bely Kamen. The research results reflect the nature of vegetation cover transformation in these islands. In particular, we have noted the flora shrinkage, community mosaicity, die-off of separate trees and entire forest communities, and abundance of nitrophilous plant species. It is emphasized that there is an adventitization of plant communities due to the increased phytocenotic role of some alien species, but we havn't revealed any growth of advent plants in the flora. The impact of bird colonies on the islands of Chivyrkuy Bay is quite similar to that on marine islands. Taking into account the normalcy of the high population size of cormorants, we have concluded that ornithogenic processes of vegetation cover transformation should not be assessed as negative process.

Keywords: flora; vegetation; the great cormorant; the Mongolian gull; ornithogenic factors; vegetation cover transformation; Baikal; seven islands of Chivyrkuy Bay. 